\title{
Identification of Hotspot for Screening for Resistance against Cotton Boll Rot Complex in Northern Karnataka, India
}

\author{
M. Nanda and V. R. Kulkarni* \\ (Plant Pathology) Agricultural Research Station, Dharwad, University of Agricultural \\ Sciences, Dharwad 580 005, Karnataka, India \\ *Corresponding author
}

A B S T R A C T

\begin{tabular}{l} 
Ke y w o r d s \\
$\begin{array}{l}\text { Cotton, Boll rot } \\
\text { complex, Hotspot, } \\
\text { Northern Karnataka }\end{array}$ \\
\hline Article Info \\
\hline $\begin{array}{l}\text { Accepted: } \\
18 \text { May 2020 } \\
\text { Available Online: } \\
\text { 10 June 2020 }\end{array}$ \\
\hline
\end{tabular}

The roving survey was undertaken in five districts of northern parts of Karnataka viz., Belagavi, Dharwad, Gadag, Haveri and Uttara Kannada. Maximum disease severity was observed in Uttara Kannada district with 10.16 Percent Disease Index (PDI) at boll initiation stage and 30.94 PDI at boll maturity stage which was followed by Dharwad district. However, minimum disease incidence i.e., 7.71 PDI at boll initiation stage and 24.70 PDI at boll maturity stage was recorded in Gadag district. Observations regarding geographical coordinates indicated that the disease complex showed an increasing trend with the increase in latitude from $14^{\circ} \mathrm{N}$ to $17^{\circ}$ $\mathrm{N}$ and showed a declining trend with the increase in distance from $74^{\circ} \mathrm{E}$ to $76^{\circ} \mathrm{E}$ with maximum disease severity at the elevation of $500 \mathrm{~m}$ to $600 \mathrm{~m}$ at both the growth stages of boll. Maximum disease incidence was noticed on bolls at lower part of the plant compared to those of mid and upper parts. Regions under Hilly zone (Zone 9) recorded maximum average disease incidence i.e., 10.75 PDI at boll initiation stage and 30.77 PDI at boll maturity stage.

\section{Introduction}

Cotton is native to tropical and subtropical regions of the world, mainly to the countries of Africa, Asia and South America. The current world production of cotton is approximately 121.37 million bales. Among the major producers in the world, India, China, United States, Pakistan and Brazil stand out. India stands first in production with 37.70 million bales under the area of 122 lakh hectares with productivity of $524 \mathrm{~kg} / \mathrm{ha}$. Amongst the Indian states, Karnataka ranks sixth in area with 5.65 lakh hectares and 
fourth in production with 19.0 lakh bales of lint with the productivity of $572 \mathrm{~kg} / \mathrm{ha}$ (Anon., 2018). Cotton is mainly cultivated in Bagalkote, Belagavi, Bellari, Chamarajanagara, Chitradurga, Davangere, Dharwad, Gadag, Haveri, Mysuru, Raichur, Shivamogga and Vijayapura districts.

Cotton is vulnerable to many biotic and abiotic stresses which accounts for its low yield potential and in turn the high cost of production. Fusarium wilt, Verticillium wilt, Alternaria blight, angular leaf spot, boll rot and leaf curl are the major diseases which are responsible for loss of yield and quality parameters in cotton.

Cotton boll rot complex is a disease condition where the associations of many pathogens influence the appearance and quality of mature cotton bolls. Infected boll may not mature completely, or if it matures under an area of high humidity, fungal organisms may attack the boll before it can open and the fibers dry (Stewart, 2007).

Cotton boll rot can be caused by various pathogens, especially the fungi Colletotrichum gossypii South., Alternaria macrospora Zimm., A. alternate (Fries) Keissler, Botryodiplodia theobromae Pat, Diplodia gossypina Cke., Exserohilum rostratum (Drechsler) Leonard and Suggs, Fusarium spp., Aspergillus niger, Rhizopus spp., Trichothecium roseum (Pers.) Link., Ramularia areolaAtk. and the bacterium Xanthomonas citri subsp. malvacearum (Smith) Schaad.

In recent years, in northern Karnataka diseases under $\mathrm{Bt}$ cotton has increased considerably and has lead to cotton boll rot complex due to favourable environment. The losses in cotton crops caused by cotton boll rot have increased and the disease complex is considerably affecting the production chain, either by production losses and/or fibre quality. Since, the information regarding boll rot complex is inadequate, the current investigation was undertaken.

\section{Materials and Methods}

Roving survey was conducted during kharif2017 cropping season to know the prevalence and severity of boll rot in major cotton growing districts of northern parts of Karnataka viz., Belagavi, Dharwad, Gadag, Haveri and Uttara Kannada. In each district two to three talukas were selected, in each taluka three to four villages were selected and in each village minimum of five fields were selected randomly on the survey route. In each field nearly three to five plants were selected and the observations for incidence and severity of disease complex were recorded with infected boll samples at lower, mid and upper parts of the plant at boll initiation and maturity stages. Each village sampling point was marked with Global Positioning System (GPS) for elevation and coordinates. Observations on disease severity, stage of the crop, variety, the condition under which the crop was grown (rainfed or irrigated) and other details were noted down. Disease severity was recorded by following 09 disease rating scale as given below.

The severity was recorded by following 0-9 disease scale (Mayee and Datar, 1986) (Table A).

Further, these scales were converted into Per cent Disease Index (PDI) by using the formula given by Wheeler (1969).

Per cent disease incidence $=$

Number of infected bolls $\times 100$

Total number of bolls observed per plant 
$\mathrm{PDI}=$

Sum of all the individual disease ratings

No. of bolls assessed $\mathrm{x}$ Maximum disease grade

\section{Results and Discussion}

The survey revealed that the disease severity ranged from 5.70 to $11.92 \mathrm{PDI}$ at boll initiation stage with maximum incidence on bolls at lower part of plants when compared to those of middle and upper parts of plants. This may be due to the acropetallous nature of boll development and closeness of bolls to the ground surface. The change in disease situation at different stages of boll development suggests that climatic conditions, availability of the inoculum and susceptibility of host to disease are different at a given stage of host. When two stages were compared, the boll maturity stage had maximum disease intensity which may be attributed to the build up of inoculum on early stages

At boll maturity stage 22.69 to 31.58 PDI was recorded with 5.27 to 21.67 per cent, 21.57 to 38.51 per cent and 46.67 to 61.85 per cent incidence on bolls at upper, middle and lower parts of plants, respectively.

The maximum average boll rot severity (11.92 PDI) at boll initiation stage was observed in Kalghatagi taluka of Dharwad district followed by Yellapur (10.19 PDI) and Mundgod (10.14 PDI) talukas of Uttara Kannada district. However, the minimum average severity was noticed in Naragund taluka of Gadag district (5.70 PDI). Irrespective of the places surveyed, the maximum incidence of the disease was observed on bolls at lower part of the plants.

Among the five districts surveyed, the maximum average severity of boll rot was recorded in Uttara Kannada (10.16 PDI) followed by Dharwad (9.57 PDI), Belagavi (9.50 PDI) and Haveri (8.03 PDI). However, the minimum average severity was noticed in Gadag (7.71 PDI).

The maximum average boll rot severity (31.58 PDI) at boll maturity stage was observed in Yellapur taluka of Uttara Kannada district followed by Kalghatagi taluka of Dharwad district (30.43 PDI) and Mundgod taluka of Uttara Kannada district (30.30 PDI). However, the minimum average severity was noticed in Naragund taluka of Gadag district (22.69 PDI). Maximum incidence (43.33-80.00\%) of the disease was observed on bolls at lower part of the plants followed by bolls on middle (12.50-45.45 \%) and theleast on bolls at upper parts of the plants $(5.00-26.67 \%)$.

Among the five districts surveyed, the maximum average severity of boll rot was recorded in Uttara Kannada (30.94 PDI) followed by Dharwad (26.35 PDI), Belagavi (25.06 PDI) and Haveri (24.88 PDI). However, the minimum average severity was noticed in Gadag (24.70 PDI).

Data pertaining to boll rot severity at different agroclimatic zones are presented in the Fig 1. The maximum average severity of boll rot was recorded in areas under the Hilly zone (Zone 9) at both boll initiation (10.75 PDI) and maturity stage (30.77 PDI) followed by the Northern transition zone (Zone 8) with 8.90 PDI at boll initiation and 25.29 PDI at boll maturity stage. However, the minimum mean severity was recorded in areas under the Northern dry zone (Zone 3) with 8.10 PDI at boll initiation and 24.08 PDI at boll maturity stage.

Data pertaining to severity of boll rot complex at different global positioning systems are presented in Fig 2. During the survey, it was noticed that maximum severity of the disease was recorded between the latitudes $16^{\circ} \mathrm{N}$ and 
$17^{\circ} \mathrm{N}(9.63 \mathrm{PDI})$ and $14^{\circ} \mathrm{N}$ and $15^{\circ} \mathrm{N}(26.90$ PDI) at boll initiation stage and maturity stage, respectively. Disease severity recorded an increasing trend at boll initiation stage and a declining trend at boll maturity stage, as the latitude increased from $14^{\circ} \mathrm{N}$ to $17^{\circ} \mathrm{N}$. In relation to longitude, a declining trend of disease severity was observed as the distance moved from $74^{\circ}$ E to $76^{\circ}$ E. Severity of boll rot was maximum between the elevation of $500 \mathrm{~m}$ and $600 \mathrm{~m}$ at both boll initiation $(9.32$ PDI) and maturity stages (27.00 PDI).

During the survey, it was noticed disease severity recorded an increasing trend at boll initiation stage and a declining trend at boll maturity stage, as the latitude increased from $14^{\circ} \mathrm{N}$ to $17^{\circ} \mathrm{N}$. In relation to longitude, a declining trend of disease severity was observed as the distance moved from $74^{\circ} \mathrm{E}$ to $76^{\circ}$ E. Severity of boll rot was maximum between the elevation of $500 \mathrm{~m}$ and $600 \mathrm{~m}$ at both boll initiation (9.32 PDI) and maturity stages (27.00 PDI).

It is clear from the results of present investigation that the boll rot complex is severe in all the areas surveyed. However, the maximum severity was found in villages of Uttara Kannada and Dharwad districts and the least was observed in villages of Gadag district (Table 1). In all the areas surveyed, there was a high incidence of Alternaria blight and bacterial blight, which can be accounted as the source of inoculum for boll rot complex. Such variations in severity and wide spread nature have been reported by Naik and Hiremath (2003).

Table.A

\begin{tabular}{|c|l|l|}
\hline $\begin{array}{c}\text { Disease } \\
\text { rating scale }\end{array}$ & \multicolumn{1}{|c|}{ Description } & \multicolumn{1}{c|}{ Category } \\
\hline $\mathbf{0}$ & No symptoms on bolls & Absolute resistant (AR) \\
\hline $\mathbf{1}$ & $1 \%$ or less bolls exhibiting boll rot symptoms & Highly resistant (HR) \\
\hline $\mathbf{3}$ & $1-10 \%$ of bolls exhibiting symptoms & Moderately resistant (MR) \\
\hline $\mathbf{5}$ & $11-20 \%$ of bolls exhibiting symptoms & Moderately susceptible (MS) \\
\hline $\mathbf{7}$ & $21-50 \%$ of bolls exhibiting symptoms & Susceptible (S) \\
\hline $\mathbf{9}$ & $51 \%$ or more bolls exhibiting symptoms & Highly susceptible (HS) \\
\hline
\end{tabular}

Table.1 Survey for cotton boll rot complex in northern parts of Karnataka during kharif 2017

\begin{tabular}{|c|c|c|c|c|c|c|}
\hline District & Taluka & $\begin{array}{l}\text { Agroclimatic } \\
\text { zone }\end{array}$ & $\begin{array}{l}\text { Elevation }(\mathbf{m}), \\
\text { Latitude }\left({ }^{0} \mathbf{N}\right) \text { and } \\
\text { Longitude }\left({ }^{\circ} \mathbf{E}\right)\end{array}$ & $\begin{array}{l}\text { Crop } \\
\text { stage }\end{array}$ & $\begin{array}{c}\text { Per cent } \\
\text { disease } \\
\text { index }(P D I)\end{array}$ & Disease Incidence (\%) \\
\hline \multirow[t]{8}{*}{ Belagavi } & \multirow[t]{2}{*}{ Bailhongal } & \multirow{2}{*}{$\begin{array}{c}\text { Northern } \\
\text { Transition Zone } \\
\text { (Zone 8) }\end{array}$} & \multirow{2}{*}{$\begin{array}{c}\text { EL } 664 \\
\text { N } 15^{0} 817^{\prime} \\
\text { E } 74^{0} 867\end{array}$} & BI & 9.39 & $\mathrm{~L}$ \\
\hline & & & & $\mathrm{BM}$ & 25.17 & $\mathrm{U}(13.54) \mathrm{M}(26.54) \mathrm{L}(59.92)$ \\
\hline & \multirow[t]{2}{*}{ Belagavi } & \multirow{2}{*}{$\begin{array}{c}\text { Northern } \\
\text { Transition Zone } \\
\text { (Zone 8) }\end{array}$} & \multirow{2}{*}{$\begin{array}{l}\text { EL } 784 \\
\text { N } 15^{0} 51 \\
\text { E } 74^{0} 30^{\prime}\end{array}$} & BI & 9.37 & $\mathrm{~L}$ \\
\hline & & & & $\mathrm{BM}$ & 25.79 & $\mathrm{U}(14.59) \mathrm{M}(24.88) \mathrm{L}(60.54)$ \\
\hline & \multirow[t]{2}{*}{ Gokak } & \multirow{2}{*}{$\begin{array}{l}\text { Northern Dry } \\
\text { Zone (Zone 3) }\end{array}$} & \multirow{2}{*}{$\begin{array}{c}\text { EL } 570 \\
\text { N } 16^{0} 1667 \\
\text { E } 74^{0} 8333\end{array}$} & BI & 9.22 & $\mathrm{~L}$ \\
\hline & & & & $\mathrm{BM}$ & 24.20 & $\mathrm{U}(5.27) \mathrm{M}(38.51) \mathrm{L}(56.20)$ \\
\hline & \multirow[t]{2}{*}{ Hukkeri } & \multirow{2}{*}{$\begin{array}{c}\text { Northern } \\
\text { Transition Zone }\end{array}$} & \multirow{2}{*}{$\begin{array}{c}\text { EL 631 } \\
\text { N } 16^{0} 23\end{array}$} & BI & 10.04 & $\mathrm{~L}$ \\
\hline & & & & BM & 24.78 & $\mathrm{U}(14.80) \mathrm{M}(28.50) \mathrm{L}(56.70)$ \\
\hline
\end{tabular}




\begin{tabular}{|c|c|c|c|c|c|c|}
\hline & & (Zone 8) & E $74^{0} 6^{\prime}$ & & & \\
\hline & Savadatti & Northern Dry & EL 610 & BI & 9.49 & $\mathrm{~L}$ \\
\hline & & Zone (Zone 3) & $\begin{array}{l}\text { N } 15^{0} 7833^{\prime} \\
\text { E } 74^{0} 1167^{\prime}\end{array}$ & BM & 25.37 & $\mathrm{U}(16.32) \mathrm{M}(27.46) \mathrm{L}(56.22)$ \\
\hline & & istrict mean & & BI & 9.50 & $\mathbf{L}$ \\
\hline & & & & BM & 25.06 & $\mathrm{U}(12.90) \mathrm{M}(29.18) \mathrm{L}(57.86)$ \\
\hline Dharwad & Dharwad & Northern & EL 751 & BI & 9.18 & $\mathrm{~L}$ \\
\hline & & $\begin{array}{l}\text { Transition Zone } \\
\text { (Zone 8) }\end{array}$ & $\begin{array}{l}\text { N } 15^{\circ} 2730^{\prime} \\
\text { E } 75^{\circ} 0030^{\prime}\end{array}$ & $\mathrm{BM}$ & 25.96 & $\mathrm{U}(14.77) \mathrm{M}(28.74) \mathrm{L}(56.44)$ \\
\hline & Hubballi & Northern & EL 671 & BI & 9.18 & $\mathrm{~L}$ \\
\hline & & $\begin{array}{l}\text { Transition Zone } \\
\text { (Zone 8) }\end{array}$ & $\begin{array}{l}\text { N } 15^{0} 2142^{\prime} \\
\text { E } 75^{\circ} 0506^{\prime}\end{array}$ & $\mathrm{BM}$ & 25.65 & $\mathrm{U}(12.61) \mathrm{M}(27.86) \mathrm{L}(59.53)$ \\
\hline & Kalghatagi & Hilly Zone & EL 536 & BI & 11.92 & $\mathrm{~L}$ \\
\hline & & (Zone 9) & $\begin{array}{l}\text { N } 15^{\circ} 18^{\prime} \\
\text { E } 74^{0} 97^{\prime}\end{array}$ & BM & 30.43 & $\mathrm{U}(17.30) \mathrm{M}(24.79) \mathrm{L}(57.91)$ \\
\hline & Navalgund & Northern Dry & EL 578 & BI & 8.00 & $\mathrm{~L}$ \\
\hline & & Zone (Zone 3) & $\begin{array}{l}\text { N } 15^{0} 57^{\prime} \\
\text { E } 75^{0} 37^{\prime}\end{array}$ & BM & 24.04 & $\mathrm{U}(13.27) \mathrm{M}(28.72) \mathrm{L}(58)$ \\
\hline & & istrict mean & & BI & 9.57 & $\mathbf{L}$ \\
\hline & & & & BM & 26.35 & $U(14.49) M(27.54) L(57.97)$ \\
\hline Gadag & Naragund & Northern Dry & EL 605 & BI & 5.70 & $\mathrm{~L}$ \\
\hline & & Zone (Zone 3) & $\begin{array}{l}\text { N } 15^{\circ} 72^{\prime} \\
\text { E } 75^{0} 38^{\prime}\end{array}$ & BM & 22.69 & $\mathrm{U}(20.30) \mathrm{M}(30.74) \mathrm{L}(48.96)$ \\
\hline & Shirahatti & Northern & EL 659 & BI & 9.72 & $\mathrm{~L}$ \\
\hline & & $\begin{array}{l}\text { Transition Zone } \\
\text { (Zone 8) }\end{array}$ & $\begin{array}{l}\text { N } 15^{0} 23^{\prime} \\
\text { E } 75^{\circ} 58^{\prime}\end{array}$ & $\mathrm{BM}$ & 26.71 & $\mathrm{U}(16.53) \mathrm{M}(24.50) \mathrm{L}(58.97)$ \\
\hline & & istrict mean & & BI & 7.71 & $\mathbf{L}$ \\
\hline & & & & BM & 24.70 & $\mathrm{U}(\mathbf{1 8 . 4 1}) \mathrm{M}(\mathbf{2 7 . 6 2 )} \mathrm{L}(\mathbf{5 3 . 9 7})$ \\
\hline Haveri & Byadgi & Northern & EL 626 & BI & 7.55 & $\mathrm{~L}$ \\
\hline & & $\begin{array}{c}\text { Transition Zone } \\
\text { (Zone 8) }\end{array}$ & $\begin{array}{l}\text { N } 14^{0} 6883^{\prime} \\
\text { E } 75^{\circ} 4886^{\prime}\end{array}$ & $\mathrm{BM}$ & 23.98 & $\mathrm{U}(11.19) \mathrm{M}(33.78) \mathrm{L}(55.02)$ \\
\hline & Haveri & Northern & EL 571 & BI & 7.13 & $\mathrm{~L}$ \\
\hline & & $\begin{array}{l}\text { Transition Zone } \\
\text { (Zone 8) }\end{array}$ & $\begin{array}{l}\text { N } 14^{0} 4738^{\prime} \\
\text { E } 75^{0} 2414^{\prime}\end{array}$ & $\mathrm{BM}$ & 23.14 & $\mathrm{U}(21.67) \mathrm{M}(31.66) \mathrm{L}(46.67)$ \\
\hline & Savanur & Northern & EL 573 & BI & 8.66 & $\mathrm{~L}$ \\
\hline & & $\begin{array}{l}\text { Transition Zone } \\
\text { (Zone 8) }\end{array}$ & $\begin{array}{l}\text { N 14 } 4^{0} 5823^{\prime} \\
\text { E } 75^{0} 1958^{\prime}\end{array}$ & BM & 25.30 & $\mathrm{U}(14.66) \mathrm{M}(28.00) \mathrm{L}(57.28)$ \\
\hline & Shiggavi & Northern & EL 601 & BI & 8.79 & $\mathrm{~L}$ \\
\hline & & $\begin{array}{l}\text { Transition Zone } \\
\text { (Zone 8) }\end{array}$ & $\begin{array}{l}\text { N 14 } 4^{0} 991 \\
\text { E } 75^{\circ} 223^{\prime}\end{array}$ & $\mathrm{BM}$ & 27.11 & $\mathrm{U}(15.69) \mathrm{M}(28.16) \mathrm{L}(56.15)$ \\
\hline & & istrict mean & & BI & 8.03 & $\mathbf{L}$ \\
\hline & & & & BM & 24.88 & $\mathrm{U}(\mathbf{1 5 . 8 0}) \mathrm{M}(\mathbf{3 0 . 4 0 )} \mathrm{L}(\mathbf{5 3 . 7 8})$ \\
\hline Uttara & Mundgod & Hilly Zone & EL 564 & BI & 10.14 & $\mathrm{~L}$ \\
\hline Kannada & & (Zone 9) & $\begin{array}{l}\mathrm{N} 14^{0} 97^{\prime}, \\
\text { E } 75^{0} 03\end{array}$ & $\mathrm{BM}$ & 30.30 & $\mathrm{U}(14.94) \mathrm{M}(31.52) \mathrm{L}(53.53)$ \\
\hline & Yellapur & Hilly Zone & EL 541 & BI & 10.19 & $\mathrm{~L}$ \\
\hline & & (Zone 9) & $\begin{array}{l}\text { N } 14^{0} 97^{\prime} \\
\text { E } 74^{0} 72^{\prime}\end{array}$ & $\mathrm{BM}$ & 31.58 & $\mathrm{U}(16.57) \mathrm{M}(21.57) \mathrm{L}(61.85)$ \\
\hline & & istrict mean & & BI & 10.16 & $\mathbf{L}$ \\
\hline & & & & BM & 30.94 & $\mathrm{U}(\mathbf{1 5 . 7 6 )} \mathrm{M}(\mathbf{2 6 . 5 5 )} \mathrm{L}(\mathbf{5 7 . 6 9})$ \\
\hline
\end{tabular}

EL: Elevation, N: North, E: East, BI: Boll Initiation, BM: Boll Maturity, AB: Alternaria blight, BB: Bacterial blight,

GM: Grey mildew. Bolls at upper (U), middle (M) and lower parts (L) of the plant 

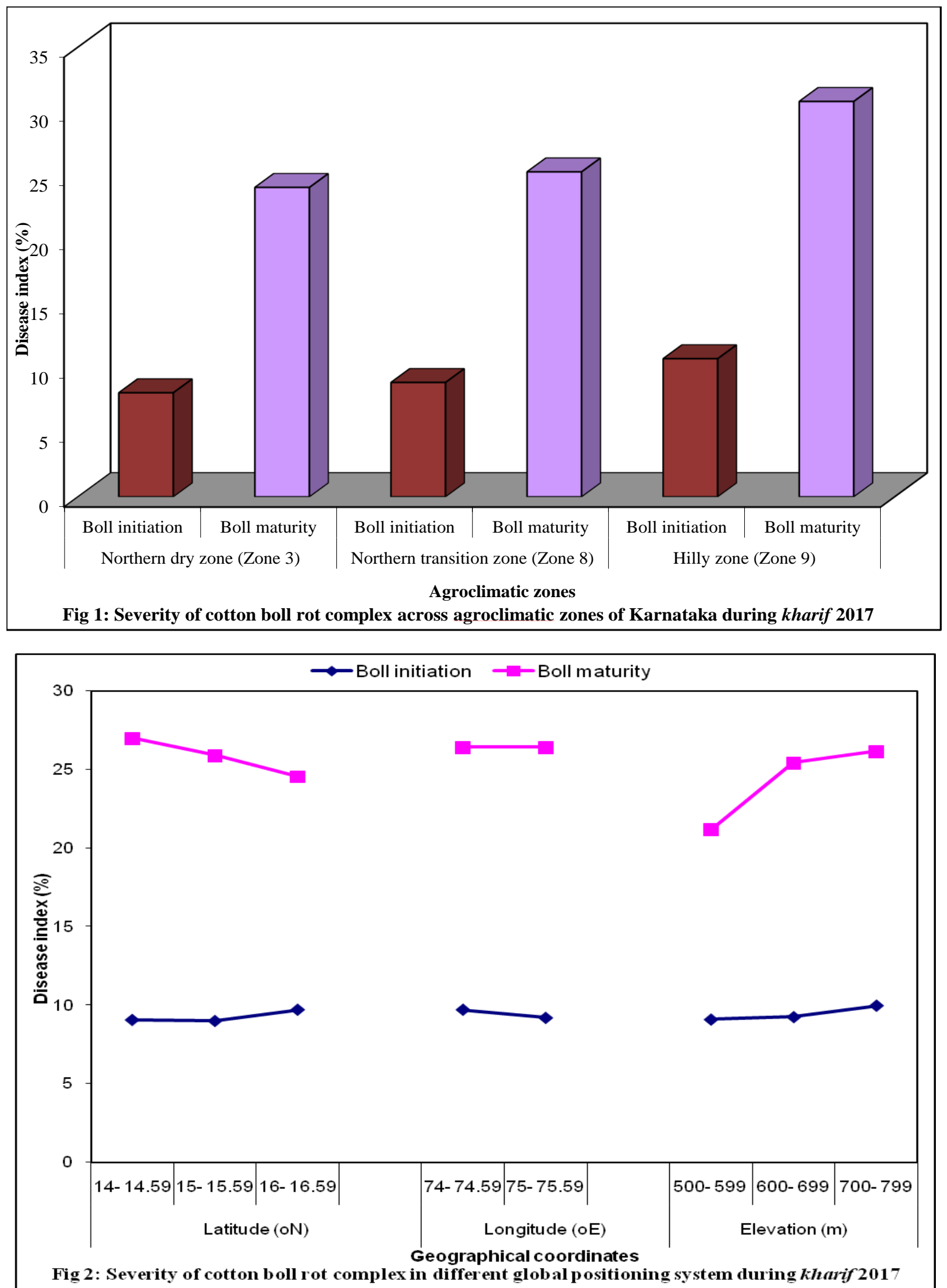
Bolls at the lower part of plants suffered greatly from the disease whereas the bolls at middle and upper parts of plants showed less severity (Fig 1). This may be due to the acropetallous nature of boll development and closeness of bolls to the ground surface. The change in disease situation at different stages of boll development suggests that climatic conditions, availability of the inoculum and susceptibility of host to disease are different at a given stage of host. When two stages were compared, the boll maturity stage had maximum disease intensity which may be attributed to the build up of inoculum on early stages (Fig 2). These findings are in agreement with Iamamoto (2007).

Among the talukas surveyed, Yellapur, Kalghatagi and Mundgod have recorded the maximum disease severity. These talukas lie under the Hilly zone which receives more than $1050 \mathrm{~mm}$ rainfall annually and has hot, moist and sub-humid climate. When bolls were exposed to long drizzling rain, spread of the disease was faster, as spores carried in raindrops reach healthy bolls and germination and establishment of the pathogen takes place. These findings are in agreement with the work of Halisky and Satour (1964), Ranneyet al., (1971) and Naik and Hiremath (2003). The least mean disease severity was observed in talukas under Northern dry zone, which may be due to the low rainfall pattern and dry climatic conditions. The study brought at first time the influence of geographical coordinates with severity of boll rot complex.

\section{References}

Anonymous, 2018. All India Coordinated Cotton Improvement Project, Annu. Rep. (2017-18 ) Coimbatore, India, pp $1-5$

Halisky P.M, Satour M.M. 1964, Evaluating fungicides for the control of Rhizopus boll rot of cotton. Plant Dis Rep 48:349363

Iamamoto M.M, 2007, Diseases of Cotton. Foundation for research, teaching and extension, Jaboticabal, Brazil, p 62

Mayee C.D, Datar V.V., 1986, Phytopathometry. Marathwada Agricultural University, Parbhani, p 126

Naik S.T, Hiremath R.V., 2003, Management of important diseases of cotton in high rainfall (Malnad) tract of Karnataka. Karnataka J Agric. Sci 16(4):620-623

Ranney C.D, Hurth J.S, Newton O.H., 1971, Effects of cotton defoliation on microclimate and reduction of boll rot of cotton. Agron J 63(2): 259.

Stewart J.M., 2007, Boll development and seed rot. Paper presented In: World Cotton Research Conference-4, Lubbock, Texas, USA, September 1014, pp.

Wheeler B.E.J., 1969, An Introduction to Plant Disease. John Wiley Sons Limited, London, p 301.

\section{How to cite this article:}

Nanda, M. and Kulkarni, V. R. 2020. Identification of Hotspot for Screening for Resistance against Cotton Boll Rot Complex in Northern Karnataka, India. Int.J.Curr.Microbiol.App.Sci. 9(06): 1845-1851. doi: https://doi.org/10.20546/ijcmas.2020.906.229 